УДК 343

DOI https://doi.org/10.32838/2707-0581/2020.1/31

\title{
Пенькова T.I.
}

Вінницький торговельно-економічний інститут

Київського національного торговельно-економічного університету

Геzа B.O.

Вінницький торговельно-економічний інститут

Київського національного торговельно-економічного університету

\section{КРИМІНАЛЬНА ВІДПОВІДАЛЬНІСТЬ ЗА ПРИМУШЕННЯ ДО ШЛЮБУ}

У статті розглядаються особливості криміналізації примушування до вступу у шлюб в Украӥна та за кордоном, проведено аналіз досвіду й меж покарання цього злочину. За основу взяті Кримінальні кодекси, а також Конституиії. Проаналізовано кримінальне законодавства іноземних країн, а саме: Францї, Сербії, Нідерландів і Чорногорії. Виявлено певні недоліки криміналізачії примушування до вступу в шлюб в Україні: деякі моменти, які потребують уточнення й удосконалення. Може навіть скластися так, щьо ие призведе до появи в украйнському законодавстві ще однієї «мертвої» норми. Проаналізовано можливість незалежної кримінальної заборони примусу до шлюбу. Розглядаються деякі фактори, сукупність яких сприяла б існуванню окремої статті про кримінальну відповідальність за зазначений злочин. Зроблено висновок щодо иъого закону в системі судової практики України. Як висновок можна припустити, що криміналізація примусу до шлюбу призведе до зайвої конкуренції кримінально-правових норм, і иілком імовірно, що в Кримінальному кодексі Украйни з'явиться ще одна «мертва» норма. Тема є особливо актуальною, оскільки, за статистикою, 10\% шлюбів в Украӥні припадають на перший рік спільного життя, лише одна з трьох пар не розлучена. Досліджено проблеми криміналізачії примусового примусу в контексті ичивільних наслідків в Україні. Згадуються недоліки статті 151-2 Кримінального кодексу Украӥни щяодо примусу до особи, яка вступає у шлюб, або продовжує вимушений шлюб, або виходить заміж без илюбу, або продовжує таке співжиття, або з метою змусити людину переміщати територію держави, яка не є тією, у якій вона проживає. Розглянуто специфіку майнового режиму пари на час припинення шлюбу або визнання його недійсним. Вивчено особливості прочесуального захисту прав та інтересів особи під час припинення шлюбу в Україні.

Ключові слова: примушування до вступу у шлюб, Конституція України, Кримінальний кодекс України, покарання, злочин, криміналізачія, суб'єкт злочину.

Постановка проблеми. У наш час суспільні відносини часто змінюються, тому виникає потреба створювати нові закони й удосконалювати їх. Особлива увага законодавця приділяється забезпеченню прав і свобод людини та громадянина. Одним із основних принципів, що відображає ставлення людини в суспільстві, $є$ принцип гуманізму, зазначений у ст. 3 Конституції України: «Людина, iї життя і здоров'я честь і гідність, недоторканність і безпека визнаються в Україні найвищою соціальною цінністю. Права і свободи людини та їх гарантії визначають зміст і спрямованість діяльності держави. Держава відповідає перед людиною за свою діяльність. Утвердження і забезпечення прав і свобод людини є головним обов'язком держави» [1].

До основних прав люди належить право на створення сім'ї та укладення шлюбу. Згідно із
Сімейним кодексом України, шлюб грунтується на вільній згоді жінки та чоловіка; примушування жінки та чоловіка до шлюбу не допускається (ст. 24); кожен із подружжя має право припинити шлюбні відносини; примушування до припинення шлюбних відносин, примушування до їх збереження, у тому числі примушування до статевого зв'язку за допомогою фізичного або психічного насильства $\epsilon$ порушенням права дружини, чоловіка на свободу й особисту недоторканність і може мати наслідки, установлені законом (ст. 56).

Згідно 3 ч. 1 ст. 3 Сімейного кодексу України, сім'я $є$ первинним та основним осередком суспільства. Однією з підстав створення сім’і $\epsilon$ шлюб, яким визначається добровільний союз жінки та чоловіка, зареєстрований у органі державної реєстрації актів цивільного стану [2]. 
Однак у наш час гостро постало питання насилля в сім’ї та можливості припинити шлюб із цієї підстави.

Аналіз останніх досліджень і публікацій. Після прийняття Конвенції Ради Свропи запровадження інституту кримінальної відповідальності за примушування до шлюбу набуло широкого розповсюдження серед країн Свропи. Криміналізація цього діяння, так само як і в Україні, пов’язана $з$ ратифікацією Конвенції Ради Свропи 2011 р. Наприклад, Кримінальний кодекс (далі КК) Франції визначає кримінально караним «факт примушування особи укласти шлюб або укладення шлюбу за кордоном шляхом уведення особи в оману задля підбурювання ii до виїзду з території Республіки, - карається трьома роками позбавлення волі та штрафом у розмірі 45000 євро» [9].

КК Сербії в ч. 1 ст. 187 визначає, що «той, хто силою або погрозами змушує іншу особу укласти шлюб, - карається позбавленням волі на строк від трьох місяців до трьох років. Той, хто з метою вчинення злочину, зазначеного в ч. 1 ст. 187, має намір вивезти особу закордон або особисто виїхати за кордон, - карається позбавленням волі на строк, не перевищує двох років» [10].

У КК Нідерландів відповідальність за примушування до шлюбу встановлена ст. 284: «... будьяка особа, яка: 1) незаконно змушує іншу особу діяти або утримуватися від певних дій або терпіти певні дії через акт насильства чи будь-яке інше діяння або загрози насильства, або загрози будьяким іншим діянням, спрямованим проти цього іншого або проти інших осіб; 2) змушує іншу особу діяти або утримуватися від певних дій або терпіти певні дії через загрозу обмовляння або наклепу - карається позбавленням волі, яке не перевищує дев'яти місяців або штрафом третьої категорії (до 8200 євро)» [11].

Стаття 214 КК Чорногорії встановлює відповідальність не тільки за примушування до шлюбу, а й за обман під час укладення шлюбу: «... кожний, хто укладає шлюб, приховуючи від іншої сторони факт, що робить шлюб недійсним, або хто обманює чи вводить іншу сторону в оману щодо цього факту, - карається позбавленням волі від трьох місяців до трьох років. Той, хто примушує або погрожує іншій особі укласти шлюб, - карається позбавленням волі на строк від шести місяців до п’яти років» [12].

Разом із тим варто зазначити, що в кримінальному законодавстві деяких країн Європи й раніше містилися статті, які передбачали можливість притягнення до відповідальності за при- мушування до шлюбу. Показовим у цьому плані $\epsilon$ положення глави 25 «Злочини проти свободи» розділу 8 «Примус» КК Фінляндії, відповідно до якого особу, «що незаконно насильством або погрозою змушує іншу робити, терпіти або не робити щось, якщо більш суворе покарання не передбачено в інших законах», можна засудити за примус до штрафу або позбавлення волі на строк не більше ніж два роки, яке є чинним із 1 вересня 1995 року [13].

6 грудня 2017 року прийнятий Закон України «Про внесення змін до Кримінального та Кримінального процесуального кодексів України з метою реалізації положень Конвенції Ради Свропи про запобігання насильству стосовно жінок і домашньому насильству та боротьбу із цими явищами» [4]. Цим Законом розділ III Особливої частини КК України доповнений ст. 151-2 «Примушування до шлюбу» [5].

Так, у ст. 151-2 КК України зазначено: «Примушування особи до вступу в шлюб або до продовження примусово укладеного шлюбу, або до вступу у співжиття без укладання шлюбу, або до продовження такого співжиття, або спонукання 3 цією метою особи до переміщення на територію іншої держави, ніж та, в якій вона проживає, караються арештом на строк до шести місяців або обмеженням волі на строк до трьох років, або позбавленням волі на той самий строк.2. Ті самі діï, вчинені повторно або за попередньою змовою групою осіб, або щодо особи, яка не досягла шлюбного віку згідно із законодавством, або щодо двох чи більше осіб, - караються обмеженням волі на строк до п'яти років або позбавленням волі на той самий строк» [14].

Постановка завдання. Криміналізація примушення до шлюбу у вітчизняному кримінальному законодавстві відбулася на виконання ст. 37 Конвенції Ради Свропи про запобігання насильству стосовно жінок і домашньому насильству та боротьбу із цими явищами. У статті 37 цієї Конвенції вказано, що сторони вживають необхідних законодавчих або інших заходів із метою забезпечення того, щоб було криміналізовано умисну поведінку, яка полягає: 1) у примушуванні дорослого або дитини до вступу у шлюб; 2) у заманюванні дорослого або дитини на території Сторони або держави іншої, ніж та, у якій він чи вона проживає, з метою примушування цього дорослого або дитини до вступу у шлюб [15].

Основним безпосереднім об'єктом зазначеного злочину $є$ воля, честь і гідність особи, зокрема, у сімейних взаєминах. Потерпілою особою може 
бути як особа, що досягла шлюбного віку, так й особа, що не досягла такого віку незалежно від статі.

3 об'єктивної сторони злочин характеризується діями в таких формах:

1) примушування особи до вступу в шлюб;

2) примушування особи до продовження примусово укладеного шлюбу;

3) примушування особи до вступу у співжиття без укладання шлюбу;

4) примушування особи до продовження такого співжиття;

5) спонукання особи до переміщення на територію іншої держави, ніж та, у якій вона проживає, 3 метою вступу в шлюб чи співжиття без укладання шлюбу або з метою продовження примусово укладеного шлюбу чи зазначеного співжиття.

Виклад основного матеріалу дослідження. Під «примушуванням» варто розуміти застосування фізичного насильства або погрози його застосування щодо потерпілої особи чи ії близької особи або шантаж - погрозу знищити чи пошкодити майно потерпілого, або викрасти потерпілого чи позбавити його волі, або розголосити відомості про потерпілого, які потерпілий бажає зберегти в таємниці, або іншим чином обмежити права, свободи чи законні інтереси потерпілого (чи його близької особи) [6]. Під спонуканням до переміщення на територію іншої держави варто розуміти заманювання особи за кордон за допомогою вигаданої причини (наприклад, відвідування хворого родича) чи в інший спосіб. Криміналізація цієї форми діяння пов'язана $з$ тим, що деяких жертв примусового шлюбу спочатку вивозять до іншої країни (нерідко до країни прабатьків), де їх примушують одружитися з громадянином цієї країни.

Окремі форми примушування підлягають додатковій кваліфікації за іншими статтями КК України. Злочин у перших чотирьох формах уважається закінченим з моменту застосування фізичної або психічної сили, а в п'ятій формі - 3 моменту вчинення дій, які характеризують зазначене спонукання (шлюб не обов'язково має бути укладений).

Суб'єкт злочину загальний. Зазвичай ним $€$ особа, яка має сімейну владу над потерпілою особою (батько, дід, мати). А якщо брати цю ситуацію до уваги із суб'єктивної сторони, то злочин може бути вчинений лише умисно. При цьому мотив і мета вчинюваних дій на кваліфікацію не вливають. Кваліфікуючими ознаками злочину (ч. 2 ст. 151-2) €:

- повторність;

- попередня змова групи осіб;

- учинення злочину щодо особи, яка не досягла шлюбного віку згідно із законодавством.

Активно реформуючи кримінально-правове поле у сфері охорони особистих прав людини на вільний вступ чи перебування у шлюбі, доцільність та актуальність чого ще має бути доведена часом, законодавець, на нашу думку, залишив поза своєю увагою більш важливий аспект реформування сімейного законодавства. Так, сьогодні в чинному законодавстві залишаються радянські архаїзми у вигляді судового способу припинення (розірвання) шлюбу в разі відсутності згоди одного 3 подружжя або наявності неповнолітніх дітей. При цьому зазначені обставини змушують особу проти іiї волі тривалий час перебувати у шлюбних відносинах до вступу рішення суду в законну сили, а суди завантажені формальними справами. Викликає подив наявність у сучасному законодавстві положень, що надають суду право на збільшення строку розгляду справи про розлучення шляхом надання місячного терміну на примирення. При цьому альтернатив судовому рішенню про розірвання шлюбу немає, тобто суд зобов'язаний і може винести лише одне рішення розірвати шлюб. Крім цього, на рівні Постанови Пленуму Верховного Суду України існує ще один рудимент, що порушує права позивача, - це вимога особисто бути присутнім сторонам під час судового процесу та неможливість використання права на представництво.

Висновки. Підводячи підсумок, варто зауважити, що ми підтримуємо намагання законодавця забезпечити правову охорону у сфері сімейних відноси, проте цілком підтримуємо висловлену окремими науковцями точку зору про відсутність достатньої обгрунтованості й доцільності криміналізації діяння, передбаченого ст. 151-2 КК України.

Список літератури:

1. Конституція України від 28.06.1996 № 254к/96-ВР. Відомості Верховної Ради України. 1996. № 30. Ст. 141.

2. Сімейний кодекс України від 10.01.2002 № 2947-III-ВР. Відомості Верховної Ради України. 2002. № 21. Ст. 135.

3. Сімейний кодекс України від 10.01.2002 № 2947-ІІІ-ВР. Відомості Верховної Ради Украӥни. 2002. № 21. Ст. 135. 
4. Про внесення змін до Кримінального та Кримінального процесуального кодексів України з метою реалізації положень Конвенції Ради Європи про запобігання насильству стосовно жінок і домашньому насильству та боротьбу з цими явищами : Закон України від 6 грудня 2017 р. № 2277. Законодавство України.

5. Відомості Верховної Ради України. 2018. № 5. Ст. 34.

6. Науково-практичний коментар Кримінального кодексу України / за ред. М.I. Мельника, М.I. Хавронюка. 10-те вид., переробл. та допов. Київ : ВД «Дакор», 2018. 1360 с.

7. Литвинов О.М., Дальниченко Ю.Б. Пропозиції та зауваження до проекту Закону України «Про внесення змін до деяких законів України у зв'язку з ратифікацією Конвенції Ради Європи про запобігання насильству стосовно жінок і домашньому насильству та боротьбу з цими явищами» (реєст. № 4952 від 12.07.2016 р.). Законодавче забезпечення правоохоронної діяльності : навчальний посібник / за заг. ред. докт. юрид. наук, доц. В.В. Сокуренка. Харків : Стильна типографія, 2017. С. 892-896.

8. Кримінальний кодекс України. Ст. 67 зі змінами, внесеними згідно із Законом України від 06.12.2017 № 2227-VIII.

9. Кримінальний кодекс Франції - ст. 222-14-4 від 25.10.2018.

10. Кримінальний кодекс Сербії - ст. 187-1.

11. Кримінальний кодекс Нідерландів - ст. 284.

12. Кримінальний кодекс Чорногорії - ст. 214.

13. Кримінальний кодекс Фінляндії - ч. 25, p. 8, від 01.09.1995.

14. Відомості Верховної Ради Украӥни. 2018. № 5. Ст. 34.

15. Конвенція Ради Європи про запобігання насильству стосовно жінок і домашньому насильству та боротьбу з цими явищами. Ст. 37.

\section{Penkova T.I., Heha V.O. CRIMINAL LIABILITY FOR FORCED MARRIAGE}

The article deals with the peculiarities of criminalization of compulsion to marry in Ukraine and abroad, analyses the experience and limits of punishment of this crime. It is based on the Criminal Codes as well as the Constitution. The analysis of the criminal legislation of foreign countries, namely France, Serbia, the Netherlands and Montenegro. Some shortcomings of the criminalization of coercion to marriage in Ukraine have been identified: some points that require further clarification and improvement. The article analyses the feasibility of having an independent criminal ban on compulsion to marry. Some factors are considered, the totality of which would favour the existence of a separate article on criminal liability for the said crime. It also draws a conclusion from its own point of view regarding this law in the system of jurisprudence of Ukraine. As a conclusion, from one point of view, we can assume that the criminalization of coercion to marriage will lead to unnecessary competition of criminal law norms, and it is likely that another "dead" rule will appear in the Criminal Code of Ukraine. The topic is especially relevant, as, according to statistics, $10 \%$ of marriages in Ukraine fall during the first year of common life, and only one of the three couples is not divorced. Problems the criminalization of coercive coercion in the context of civil consequences in Ukraine is investigated. This article mentions the shortcomings of Article 151-2 of the Criminal Code of Ukraine concerning coercion a person who marries or continues a forced marriage or marries without a marriage, or to continue such cohabitation, or in order to induce a person to move the territory of a State other than that in which it resides. Specificity of the property regime of the couple at the time of marriage termination or invalidation. Specifics procedural protection of the rights and interests of a person during the marriage termination in Ukraine.

Key words: coercion to marriage, Constitution of Ukraine, Criminal codex of Ukraine, punishment, crime, criminalization, the subject of the crime. 